\title{
INKLUSIVITAS PENGELOLAAN ALOKASI DANA DESA (ADD) BERBASIS PARTISIPASI MASYARAKAT DI DESA AIR MATA, KABUPATEN KUPANG
}

\author{
INCLUSIVENESS IN THE COMMUNITY PARTICIPATION BASED MANAGEMENT \\ OF VILLAGE ALOCATION FUND IN THE MATA AIR VILLAGE IN KUPANG \\ REGENCY
}

\author{
UMBU TW PARIANGU* \\ Program Srudi Administrasi Negara Universitas Nusa Cendana, Kupang \\ *Email: umbu.umbupariangu.pariangu25@gmail.com
}

\begin{abstract}
Abstraksi
Partisipasi masyarakat dalam Pengelolaan dana ADD di Desa Air Mata, Kelurahan Tarus, Kabupaten Kupang masih jauh dari standard yang diharapkan. Dalam hal perencanaan pengelolaan ADD masih "teknokratis" di mana hanya melibatkan elite masyarakat desa dan perangkat desa dengan mengenyampingkan partisipasi kelompok minoritas masyarakat miskin dan kelompok perempuan. Demikian pun dalam hal pelaksanaan, pengelolaan ADD yang belum terlembagakan, atau dideterminasi oleh mobilisasi instrumentalitas pemerintah dan aparat desa. Koherensi partisipasi masyarakat dalam pelaksanaan pengelolaan ADD hanya bersifat spontanitas sehingga mereduksi makna inklusifitas pengelolaan dana yang berbasis dukungan masyarakat desa. Ini menyebabkan lemahnya kontinuitas prakarsa desa dalam penegelolaan ADD yang berkonsekeuensi langsung pada tanggung jawab dan sense of belonging masyarakat terhadap dinamika pembangunan di desanya. Hal yang sama juga terjadi dalam pengawasan pengelolaan ADD yang belum menyentuh level degree of citizen power menunjukkan bahwa pengawasan pengelolaan ADD dilaksanakan secara hirarkhis-struktural tanpa melibatkan peran serta masyarakat. Warga masyarakat memang tidak diberi akses untuk bisa terlibat dalam pengawasan pengelelolaan ADD. Pengelolaan ADD di tingkat desa (Kepala Desa, PTPKD, dan Bendahara Desa) selaku penganggung jawab pegelolaan ADD di tingkat desa adalah sebagai pihak yang dipandang paling bertanggung jawab terhadap pengelolaan ADD.
\end{abstract}

Kata Kunci: inklusifitas, Alokasi Dana Desa, partisipasi masyarakat

\section{Abstract}

Community participation in the management of village allocation fund in the Village of Mata Air is still far from the required standards. At the planning stage, the management of the fund is deemed as too "technocratic" in which only village elites are involved, while the poor segment of the village residents as well as women are not involved. At the implementation stage, the fund management has neither been institutionalized nor determined by the mobilization of government instruments and village administrative personnel. So far the community participation only goes in a spontaneous way and as such has reduced the degree of inclusiveness. As a result, the continuity of villagers' initiatives is cut off and therefore it does not nurture the sense of belonging in the whole village development. At the supervision level, the fund is controlled in a structural-hierarchical way without involving the village residents. The residents are not given access to the village fund management. The village head, village finance technical executive, and the village treasurer are still considered the most responsible persons in the management of village allocation fund.

Key words: Inclusiveness, Village allocation fund, community participation 


\section{Pendahuluan}

Konsep inklusifitas dalam konteks pembangunan desa merupakan paradigma membangun lingkungan atau masyarakat secara lebih luas dengan mengakomodir keikutsertaan atau partisipasi elemen masyarakat seluas mungkin untuk memastikan bahwa programprogram pembangunan desa bisa berimplikasi bagi kepentingan masyarakat itu sendiri (Lenoir, 1974).

Pada lazimnya, terdapat tiga kausalitas partisipasi masyarakat dalam proses pembangunan, yakni: 1) Partisipasi masyarakat merupakan suatu alat guna memperoleh informasi mengenai kondisi, kebutuhan dan sikap masyarakat setempat, yang tanpa kehadirannya, proyek pembangunan atau proyek-proyek lainnya akan gagal. 2) Masyarakat akan lebih mempercayai program atau proyek pembangunan jika merasa dilibatkan dalam proses persiapan dan perencanaan, karena mereka akan lebih mengetahui seluk-beluk proyek tersebut dan akan lebih merasa memiliki (sense of belonging) terhadap proyek tertentu. 3) Dalam perspektif demokrasi, partisipasi merupakan hak masyarakat untuk dapat terlibat dalam pembangunan (Ife dan Tesoriero, 2008: 295).

Menurut Keith Davis (dalam Darmada, 2011), bentuk partisipasi masyarakat berupa (a) konsultasi biasanya dalam bentuk jasa, (b) sumbangan spontan berupa uang dan barang, (c) mendirikan proyek yang sifatnya berdikari dan donornya berasal dari sumbangan individu/ instansi yang berada di luar lingkungan tertentu (pihak ketiga), (d) mendirikan proyek yang sifatnya berdikari dan dibiayai seluruhnya oleh masyarakat, (e) sumbangan dalam bentuk kerja, (f) aksi massa, (g) mengadakan pembangunan di kalangan keluarga desa mandiri dan (h) membangun proyek komunitas yang bersifat otonom.

Partisipasi sejatinya tidak sekedar resultante melainkan suatu "proses" (Cottam, 2010: 56), sehingga partisipasi selalu bertumpu pada perubahan dalam kapasitas organisasi, komunitas individu; perubahan dalam sikap dan perilaku; perubahan dalam akses kepada sumber daya; perubahan dalam keseimbangan kekuasaan; perubahan dalam persepsi para pemangku kepentingan. Partisipasi memiliki potensi untuk berkontribusi pada perubahan penting dalam aspek-aspek politik, kultural, ekonomi dan sosial dari masyarakat dan dari kehidupan manusia (Kuncoro, 2019).

Bagi Ife dan Tesoriero (2008: 298) penting bagi pekerja masyarakat untuk memiliki pengetahuan dasar yang solid tentang suatu pendekatan informasi terhadap partisipasi untuk menciptakan partisipasi maksimum dari warga negara dalam pembuatan keputusan dalam proyek-proyek dan kegiatan pembangunan. Arnstein (1969) (dalam Ife dan Tesoriero, 2008: 299) mengusulkan model partisipasi yang memperjelas sifat berlawanan dari konsep tersebut, kerumitannya dan berbagai arti yang dimiliki. Implikasi dari berbagai arti yang berbeda bagi kekuatan juga jelas dari tangga partisipasi warga negara yang disusunnya. Tujuan penelitian ini adalah mengetahui faktorfaktor penghambat partisipasi masyarakat dalam pengelolaan ADD di Desa Mata Air, Kelurahan Tarus, Kabupaten Kupang.

\section{Metode Penelitian}

Pendekatan yang digunakan dalam penelitian ini adalah penelitian kualitatif yang oleh Moleong (1989) merupakan suatu penelitian yang bersifat objektif, dan pengumpulan data diperoleh dengan cara observasi, wawancara, dan juga studi dokumentasi untuk melakukan pengumpulan, pengolahan atau analisis data, penyusunan laporan, serta penarikan kesimpulan data yang diperoleh. Penelitian ini mengungkap gejala menyeluruh yang sesuai dengan situasi lapangan melalui pengumpulan data dari latar alami dengan memanfaatkan diri peneliti sebagai instrumen kunci (Usman, 2009 : 111), yang memiliki karakteristik cross-sectional, yang dilakukan pada periode waktu tertentu. Penelitian ini dilakukan dengan metode analisis deskriptif. Jenis data yang digunakan dalam penelitian ini yaitu data primer dan data sekunder yang diperoleh dari dokumen-dokumen yang terdapat di Desa Air Mata, Kecamatan Kupang Tengah terkait dengan Alokasi Dana Desa tahun 2018. Informan Penelitian adalah Badan Pemberdayaan Masyarakat dan Pemerintahan Desa Kabupaten Kupang, Kepala Seksi Pemerintahan 
Desa Kabupaten Kupang, Kepala Desa, Perwakilan dari Badan Permusyawaratan Desa, dan perwakilan masyarakat desa yang ditetapkan dengan teknik purposive sampling atau pengambilan sampling non-probabilitas, dengan lokasi penelitian di Desa Mata Air, Kecamatan Kupang Tengah, Kabupaten Kupang. Data kemudian dieksaminasi dengan triangulasi yakni membandingkan data hasil pengamatan dan juga hasil wawancara dari informan satu dengan informan yang lainnya, serta dengan penyelarasan antara data yang diperoleh dengan kondisi yang sesungguhnya ada (Sugiyono, 2010 : 125) dan dengan member check dengan melakukan pengecekan data yang dilakukan oleh peneliti kepada subjek penelitian atau narasumber untuk mengetahui seberapa jauh data yang diperoleh sesuai dengan yang disampaikan oleh narasumber (Usman, 2009 : 81).

\section{HASIL DAN DISKUSI}

\section{A. Gambaran Umum Desa Air Mata A.1 Sejarah dan Keadaan Geografis}

Desa Mata Air diusulkan pemekaran dari induk kelurahan Tarus pada tahun 2003, kemudian pada tanggal 16 juni tahun 2006 mendapat SK dari kementrian otonomi daerah, sehingga ditetapkan sebagai hari lahirnya/berdirinya Desa Mata Air. Desa Mata Air diusulkan oleh beberapa tokoh masyrakat yang diketahui oleh Lurah Tarus Bapak Gabriel Haning yang sekaligus sebagai ketua panitia pemekaran. Setelah pemekaran, maka ditunjuk Bapak Yakobus Kalau, SH sebagai pejabat pada tanggal 28 juni 2003, dalam perjalanannya pada tanggal 16 april 2006 terjadi pemilihan kepala desa adalah Bapak Yakobus Kalau SH, untuk masa bakti 2006-2012. Seiring berjalannya waktu, pendukung Desa Mata Air pun bertambah karena adanya keturunan dari buah perkawinan masyarakat setempat dan masuknya suku-suku wilayah lain dalam wialaya NTT maupun dari luar NTT seperti suku Flores, Sabu, Alor, Belu, Bugis, Jawa, Rote. Desa mata air termasuk dalam wilayah administrasi Kecamatan Kupang Tengah. Dengan jarak tempuh dari Ibukota Provinsi kurang lebih $1 \mathrm{Km}$ dan jarak tempuh dari Ibukota Kabupaten Kupang kurang lebih $24 \mathrm{Km}$. Desa Mata Air memiliki luas wilayah 6.000.000 km2 . Wilayah Desa Mata Air terdiri dari 32 RT, 14 RW dan 5 Dusun yaitu:

1. Dusun I : Mata Air

2. Dusun II: Boa Pua

3. Dusun III: Kampung Baru

4. Dusun IV: Oetete II

5. Dusun V: Oetete I

Dengan batas-batas wilayah sebagai berikut:

- Sebelah Timur: Berbatasan dengan Desa Noelbaki

- Sebelah Barat: Berbatasan dengan Kelurahan Tarus

- Sebelah Utara: Berbatasan dengan Teluk Kupang

- Sebelah Selatan: Berbatasan dengan Desa Oelnasi dan Penfui Timur

Jumlah penduduk Desa Air Mata adalah 5.296 orang, dengan jumlah Kepala Keluarga sebanyak 1.121. Yang terdiri dari jumlah laki-laki sebanyak 2.716 orang dan jumlah perempuan 2.580 orang. Di mana kelompok umur 31-45 tahun adalah yang paling banyak, yakni 973 orang, yang terdiri dari laki-laki : 523 orang dan perempuan: 450 orang. Selain itu, hal yang tak kalah penting di dalam penampakan profil masyarakat desa ialah tingkat pendidikan masyarakatnya yang menunjukan derajat pemahaman dan kekritisan masyarakat di dalam melaksanakan kegiatan kemasyarakatan dan pembangunan yang ada. Sejauh ini, tingkat pendidikan masyarakat di Desa Air Mata masih didominasi oleh tamatan SD sebanyak 3.673 Orang (69,37 \%). Sedangkan yang menyelesaikan perguruan tinggi hanya 184 Orang (3,48 \%). Untuk mereka yang menyelesaikan pendidikan informal seperti kursus/keterampilan sebanyak 30 Orang (0,56\%).

Meski pada prinsipnya ADD harus dikelola dengan menganut prinsip akuntabilitas, tranparansi, dan partisipasi maupun efisiensi (Permendagri No 37 Tahun 2007 dan Permendagri No 113 Tahun 2014), namun di dalam Peraturan Bupati Peraturan Bupati No.7 Tahun 2015 tentang Tata Cara Pengalokasian dan Penetapan Besaran Alokasi Dana Desa di Kabupaten Kupang Tahun Anggaran 2015 Pasal 2, tidak ada klausul yang menyebutkan mengenai pelaksanaan ADD dilakukan secara partisipatif, transparan, dan akuntabel. Kebijakan-kebijakan 
yang dilakukan oleh Dinas/Instansi terkait dengan pengeloaan ADD ini juga tidak ada yang mengatur secara lebih operasional, bahwa pengelolaan ADD dilakukan secara partisipatif, transparansi dan akuntabel. Sementara yang dijadikan rujukan operasional pengelola ADD di tingkat desa adalah Peratuan Bupati dan materi-materi pembekalan yang disampaikan oleh Dinas/Instansi terkait. Akibatnya dalam pengimplementasiannya memberikan peluang untuk terjadi penyimpangan.

Bahkan Kepala Desa Air Mata mengatakan, bahwa pelaksaan pengelolaan ADD sekalipun tidak dilaksanakan secara partisipatif, trasparan, akuntabel tidak dipermasalahkan (masih bisa ditolerir), yang penting sesuai dengan rencana kegiatan yang telah ditetapkan melalui MUSRANBANGDes. Dalam hal pertanggungjawaban, pengelolaan ADD hanya dilaksanakan oleh Kepala Desa, PTPKD dan Bendahara Desa kepada Bupati Kupang melalui Kepala Seksi Pemerintahan Kecamatan/Camat dan Bagian Tata Pemerintahan Desa Sekretariat Desa Kabupaten Kupang. Mekanisme dan prosedur dan pertanggungjawaban seperti ini telah berjalan sejak 2007 sampai dengan sekarang.

Terkait dengan pengawasan ini, peraturan atau kebijakan yang mengatur tentang pengawasan pengelolaan ADD masih kurang memberikan ruang atau akses bagi masyarakat untuk dapat terlibat dalam pengawasan pengelolaan ADD. Implikasinya, jika pengawasan pengelolaan ADD tersebut tidak melibatkan partisipasi masyarakat, maka pengelola ADD tidak bisa dipersalahkan. Fakta di lapangan juga menunjukkan, bahwa pengawasan pengelolaan ADD hanya dilaksanakan oleh Kepala Desa, PTPKD, Bendahara Desa, Kepala Seksi Pemerintahan Kecamatan/Camat dan Bagian Tata Pemerintahan Desa Sekretariat Daerah Kabupaten Kupang. Proses pelaksanaan pengawasan ini telah berlangsung sejak tahun 2007 sampai sekarang karena unsur-unsur yang terlibat dalam proses pelaksanaan pengawasan ini dianggap sudah sesuai dengan prosedur.

Partisipasi Masyarakat Dalam Pengelolaan ADD dalam Tahap Perencanaan bahwa tingkat kehadiran peserta dalam mengikuti kegiatan perencanaan pada kurun waktu 3 tahun tersebut rata-rata sekitar 69,96\% dari jumlah calon peserta yang diundang dan perkembangan tingkat kehadiran dari tahun ke tahun cenderung mengalami penurunan, yakni tahun $2015(81,48 \%)$, tahun 2016 (70,37\%) dan pada tahun 2017 (58,02\%). Penurunan ini disebabkan antara lain oleh jarak antara rumah peserta ke kantor desa yang relatif jauh, peserta tidak mendapatkan transportasi, ada yang mengalami kejenuhan karena terlalu sering mengikuti rapat dan sebagainya. Secara kualitatif tingkat partisipasi masyarakat dalam proses pelaksanaan MUSRENBANGDes memang sulit diukur karena tidak ada dokumen rekaman proses yang menggambarkan mengenai keberlangsungan proses pelaksanaan MUSRENBANGDes. Bentuk dokumen hasil pelaksanaan MUSRENBANGDes yang bisa diakses hanyalah berupa "Hasil MUSRENBANGDes" yang berisikan tentang Rencana Penggunaan Keuangan Alokasi Dana Desa” yang telah ditandatangani oleh Kepala Desa, PTPKD, LPMD dan BPD. Namun jika dilihat dari durasiwaktunya, bahwaprosesMUSRENBANGDes yang dilaksanakan kurang dari satu hari. Hal ini jelas kurang memadai untuk terjadi proses interaksi dialogis. Lebih-lebih proses MUSRENBANGDes tersebut difasilitasi langsung oleh Kepala Desa yang notabene-nya kurang memiliki dasar-dasar fasilitasi partisipatif, sehingga dapat dipastikan bahwa proses MUSRENBANGDes kurang mencerminkan prinsip atau nilai partisipatif. Secara substansial, proses perencanaan pengelolaan ADD tersebut masih belum mencerminkan prinsip partisipatif, responsifitas, transparansi dan akuntabilitas yang sebenarnya.

Dengan kata lain, proses perencanaan pengelolaan ADD tersebut masih berorientasi pada produk dokumen, kurang menyentuh pada kualitas proses perencanaan partisipatif yang sejatinya. Karena itu, proses MUSRENBANGDes yang terjadi bukan merupakan proses MUSRENBANGDes yang bisa digolongkan secara partisipatif, tetapi lebih berarti penyampaian usulan kegiatan (shoping list) pengelolaan ADD.

Di dalam tahap pelaksanaan, pengelolaan ADD di Desa Air Mata lebih banyak digunakan untuk biaya operasional perangkat desa dan 
organisasi kemasyarakatan, sedangkan untuk kegiatan pemberdayaan masyarakat yang melibatkan partisipasi masyarakat hanya berupa kerja bakti sosial dan pengelolaan Dana Bantuan Dusun. Karena itu, ruang partisipasi masyarakat dalam pengelolaan dana ADD menjadi sangat terbatas. Padahal kalau dilihat dari kultur masyarakatnya, bahwa jiwa gotong-royong masyarakatnya sangat tinggi sekali yang tecermin dari partisipasi masyarakat dalam kegiatan membangun rumah, pembersihan saranaprasarana lingkungan, pembangunan saluran pembuangan air, perbaikan jalan, bersih desa dan lain sebagainya.

Masyarakat antusias pada saat kerja bakti pembangunan lingkungan untuk kepentingan bersama. Mereka bisa berpartisipasi dalam bentuk pemberian sumbangan tenaga kerja, dan konsumsi ala kadarnya. Aspek lain yang perlu diperhatikan terkait dengan partisipasi masyarakat dalam pelaksanaan pengelolaan ADD di Desa Air Mata ini adalah bentuk, wujud dan tipologi dari partisispasi masyarakat itu sendiri. Fakta di lapangan menunjukkan, bahwa partisipasi masyarakat yang muncul adalah partisipasi yang digerakkan (dimobilisasi) oleh aparat pemerintah desa, Kepala Dusun, Ketua RW dan para Ketua RT. Realitas partisipasi masyarakat tersebut apabila dianalisis dengan menggunakan pendekatan teori partisipasi dari Anstein (dalam Wilcox, 1996) yang dikenal dengan Ledders of Participation (tangga partisipasi) maka akan diperoleh sebuah pemahaman bahwa partisipasi masyarakat dalam pelaksanaan pegelolaan ADD di Desa Air Mata masih berada dalam tataran yang terbatas dengan kategori derajat partisipasi yang disebut "Tanda Partisipasi” (tokenism) dan berada pada tangga ketiga yaitu pemberian informasi (informing). Artinya partisipasi masyarakat dalam pelaksanaan pengelolaan ADD di Desa Air Mata tersebut baru bersifat informing (pemberian informasi) dan consultation (konsultasi) saja serta belum mencapai pada tingkatan partnership (kemitraan).

Fakta lain yang menguatkan kesimpulan ini adalah keterlibatan masyarakat dalam pelaksanaan pengelolaan ADD yang lebih bersifat spontan, tidak terencana dan terlembagakan sehingga keberlanjutannya masih menjadi tanda tanya besar. Dengan kata lain partisipasi masyarakat sering kali hanya bersifat temporal dan terjadi karena didasarkan atas perintah atau instruksi dari pemerintah desa. Adapun bentuk partisipasi masyarakat dalam pelaksanaan kegiatan pengelolaan ADD tersebut meliputi: (1) instruksi kerja bakti kepada warga masyarakat, dan (2) penyampaian SKPJ pengelolaan ADD kepada BPD.

Dalam tahap pengawasan, partisipasi masyarakat, menurut Kepala Desa Air Mata, pengawasan pengelolaan ADD dilaksanakan secara hirarkhis-struktural tanpa melibatkan peran serta masyarakat. Warga masyarakat tidak diberi akses untuk bisa terlibat dalam pengawasan pengelelolaan ADD. Pihak yang paling bertanggungjawab atas pengelolaan ADD di tingkat desa adalah Kepala Desa, PTPKD, dan Bendahara Desa. Dengan demikian, partisipasi proses pengawasan oleh masyarakat terhadap pengelolaan dana ADD kurang terlihat dan nyaris tidak ada.

Masyarakat tidak ada yang mengorganisir diri untuk menjadi pengawas pelaksanaan pengelolaan dana ADD, baik secara individu maupun kelompok, dan juga tidak ada pelaporan kepada masyarakat terkait dengan hasil pelaksanaan pengelolaan dana ADD karena pertanggungjawabannya sudah masuk dalam LKPJ (Laporan Keterangan Pertanggung Jawaban) hasil pengelolaan ADD yang disampaikan kepada BPD. Akibatnya, tingkat pemahaman masyarakat terhadap proses pelaksanaan pengelolaan dana ADD dan perkembangan capaian hasil kegiatannya tidak memadai. Apalagi determinasi regulasi teknokratis (Peraturan Bupati Kupang Nomor 48 tahun 2008) yang menetapkan 2 pendekatan (pengawasan melekat dan fungsional) menjadikan pengawasan pengelolaan ADD bersifat hierarkis, dan pemerintah desa selaku penyelenggara pengelolaan ADD dalam pertanggungjawabannya lebih bertanggung jawab kepada pemerintah supradesa ketimbang masyarakat. Akibatnya lebih jauh, dengan adanya kebijakan tersebut semakin melemahkan partisipasi masyarakat dalam pengawasan pengelolaan ADD. Dengan menggunakan pendekatan teori partisipasi dari Anstein (dalam Wilcox, 1996): ledders of 
participation (tangga partisipasi), partisipasi masyarakat dalam pengawasan pengelolaan ADD di Desa Air Mata tidak bisa dikategorikan dalam degree of citizen power.

Namun partisipasi masyarakat dalam pelaksanaan pengawasan pengelolaan ADD di Desa Air Mata tersebut masih berada dalam kategori dalam derajat partisipasi yang disebut nonpartisipasi (non-participation), dan berada pada tangga ke-1 (paling bawah), yaitu "manipulasi" (manipulation). Artinya, partisipasi masyarakat dalam pengawasan pengelolaan ADD di Desa Air Mata tersebut bersifat manipulasi. Sebagai gambaran dari adanya derajat partisipasi masyarakat Desa Air Mata dalam pengelolaan ADD, mulai dari perencanaan, pelaksanaan dan pengawasan tersebut, dapat dilihat pada tabel sebagai berikut:

Tabel

Derajat partisipasi Masyarakat dalam Pengelolaan ADD di Desa Air Mata, Kelurahan Tarus, Kabupaten Kupang

\begin{tabular}{|c|c|c|}
\hline $\begin{array}{c}\text { Derajat } \\
\text { Partisipasi }\end{array}$ & Tangga Partisipasi & Mekanisme Partisipasi \\
\hline \multirow[t]{3}{*}{ Kuasa Warga } & 8. Kendali warga & \\
\hline & $\begin{array}{ll}\text { 7. } & \text { Kuasa yang } \\
\text { didelegasikan }\end{array}$ & \\
\hline & 1. Kemitraan & \\
\hline \multirow{3}{*}{$\begin{array}{c}\text { Tanda } \\
\text { Partisipasi }\end{array}$} & 5. Penentraman & \\
\hline & 1. Konsultasi & MUSRENBANGDes \\
\hline & $\begin{array}{l}\text { 3. Pemberian } \\
\text { Informasi }\end{array}$ & $\begin{array}{l}\text { - Penyampaian undangan } \\
\text { MUSRENBANGDes } \\
\text { - Penyampaian draft } \\
\text { RPD-ADD } \\
\text { - Instruksi kerja bhakti } \\
\text { kepada warga } \\
\text { masyarakat } \\
\text { - Penyampaian LKPJ } \\
\text { Pengelolaan ADD } \\
\text { kepada BPD }\end{array}$ \\
\hline \multirow[t]{2}{*}{$\begin{array}{c}\text { Non } \\
\text { Partisipasi }\end{array}$} & 2. Terapi & $\begin{array}{l}\text { - Permintaan laporan } \\
\text { kepada pengelola ADD } \\
\text { - Kunjungan Kepala Desa } \\
\text { pada suatu kegiatan } \\
\text { pengelolaan ADD }\end{array}$ \\
\hline & 1. Manipulasi & $\begin{array}{l}\text { Pengawasan dan } \\
\text { pengelolaan ADD oleh } \\
\text { BPD }\end{array}$ \\
\hline
\end{tabular}

Berdasarkan tabel di atas, dapat digambarkan bahwa partisipasi masyarakat Desa Air Mata, Kelurahan Tarus, Kabupaten Kupang dalam pengelolaan $\mathrm{ADD}$ hanya mencapai tangga ke4, yaitu tangga konsultasi. Bentuk kegiatan pengelolaan $\mathrm{ADD}$ yang mencapai tangga ke- 4 ini adalah MUSRENBANGDes. Sedangkan bentuk kegiatan pengelolaan ADD yang menempati tangga pemberian informasi yang paling banyak, yaitu (1) Penyampaian undangan MUSRENBANGDes, (2) Penyampaian draft RPD-ADD, (3) Instruksi kerja bakti kepada warga masyarakat, dan (4) Penyampaian SKPJ pengelolaan ADD kepada BPD.

Ada tiga bentuk kegiatan pengelolaan ADD yang masuk dalam kategori derajat nonpartisipasi. Dua (2) kegiatan berada pada tangga ke-2 (terapi), yaitu: (1) Permintaan laporan kepada pengelola ADD, dan (2) Kunjungan Kepala Desa pada suatu kegiatan pengelolaan ADD, dan satu (1) kegiatan berada pada tangga ke-1 (manipulasi), yaitu: pengawasan pengelolaan ADD oleh masyarakat (yang diwakili oleh BPD).

Dapat disimpulkan bahwa partisipasi masyarakat Desa Air Mata dalam pengelolaan ADD dengan menggunakan teori partisipasi dari Anstein (dalam Wilcox, 1996): "Ledder of participation", partisipasi masyarakat dalam pengelolaan ADD di Desa Air Mata Kabupaten Kupang tersebut hanya masuk dalam derajat partisipasi "tokenisme" (tanda partisipasi) dan berada pada tangga ke-4 yaitu: consultation (konsultasi) dengan bentuk kegiatan MUSRENBANGDes. Bentuk kegiatan pengelolaan ADD yang paling banyak adalah bentuk kegiatan yang menempati tangga ke-3 (informing), yaitu: (1) penyampaian undangan MUSRENBANGDes, (2) penyampaian draft RPD-ADD, (3) instruksi kerja bhakti kepada warga masyarakat dan, (4) penyampaian LKPJ (Laporan Keterangan Pertanggungjawaban) hasil pengelolaan ADD kepada BPD. Bahkan ada 3 bentuk kegiatan pengelolaan ADD yang masuk dalam kategori derajat partisipasi "non-participation" (nonpartisipasi), 2 bentuk kegiatan berada pada tangga ke-2 (terapi), yaitu: (1) Permintaan laporan kepada pengelola $\mathrm{ADD}$, dan (2) kunjungan Kepala Desa pada suatu kegiatan pengelolaan ADD, dan 1 bentuk kegiatan lagi yang berada pada tangga ke-1 
(manipulasi), yaitu: pengawasan pengelolaan ADD oleh BPD yang diasumsikan sebagai representasi dari masyarakat. Dalam tahap perencanaan, partisipasi masyarakat pada tahap perencanaan ini secara umum dapat dikatakan masih bersifat semu.

Hal ini mengindikasikan bahwa kehadiran peserta dalam kegiatan perencanaan atau MUSRENBANGDes tersebut lebih berfungsi sebagai pendengar, karena proses MUSRENBANGDes lebih didominasi oleh elite desa. Lebih daripada itu, dalam proses MUSRENBANGDes itu, draf rencana penggunaan ADD sudah dipersiapkan oleh pemerintah desa, sehingga peserta MUSRENBANGDes cenderung untuk mengiyakan atau menyetujui draft rencana penggunaan ADD yang sudah disiapkan tersebut. Dengan demikian proses perencanaan pengelolaan ADD masih kurang memerhatikan prinsip responsibilitas, partisipasi, transparansi dan akuntabilitas. Dalam istilahnya Anstein, partisipasi masyarakat yang demikian ini masuk dalam kategori derajat partisipasi yang disebut "tokenisme". Bentuk kegiatan partisipasi masyarakat dalam pengelolaan ADD tersebut paling banyak berada pada tangga ke-3 yaitu pemberian informasi (informing), dan masyarakat hanya diajak konsultasi (consultation) untuk dimintai persetujuan terhadap draft Rencana Penggunaan Keuangan ADD yang sudah dipersiapkan oleh aparat pemerintah desa.

Pada tahap pelaksanaan pengelolaan ADD, keikutsertaan masyarakat hanya terlibat pada kegiatan gotong royong kerja lingkungan dan pemanfaatan pengelolaan dana bantuan dusun yang diperoleh dari ADD. Sedangkan untuk pelaksanaan kegiatan pengelolaan dana ADD lainnya ditangani oleh para pihak pelaksana kegiatan yang telah ditunjuk dan dilaksanakan oleh pemerintah desa. Dalam istilahnya Anstein, partisipasi masyarakat yang demikian ini masuk dalam derajat partisipasi yang disebut "tokenisme", yang mencapai anak tangga ke-3 (Informing). Artinya masyarakat hanya diberi informasi (informing) untuk melaksanakan kegiatan yang elah diinstruksikan aparat pemerintah desa.

Sedangkan dalam tahap pengawasan, keterlibatan masyarakat tidak ada sama sekali.
Masyarakat tidak diberi akses dalam melakukan pengawasan terhadap pengelolaan ADD. Lebih daripada itu, hasil pelaksanaan pengelolaan ADD tidak dipertanggungjawabkan secara langsung kepada masyarakat dan BPD (Badan Perwakilan Desa), tetapi para pelaksana kegiatan pengelolaan ADD tersebut melaporkan langsung kepada PTPKD (Pelaksana Teknis Penggunaan Keuangan Desa), dan bendahara desa. Selanjutnya laporan hasil kegiatan pengelolaan ADD tersebut dilaporkan kepada Kepala Desa, kemudian diteruskan pada Bagian Tata Pemerintahan Desa melalui Kecamatan. Karena itu tingkat transparansi dan akuntabilitas dari pelaksanaan pengelolaan ADD tersebut bisa dikatakan lemah dan patut dipertanyakan, karena tidak adanya keterlibatan masyarakat dalam pengawasan pengelolaan ADD. Gambaran proses pengawasan tersebut kalau dianalisis dengan menggunakan teori partisipasi dari Anstein (dalam Wilcox, 1996) bisa dikategorikan dalam derajat partisipasi masyarakat yang demikian ini masuk dalam derajat partisipasi yang disebut "nonparticipation”.

Ada 2 bentuk kegiatan yang berada pada tangga ke-2 (terapi), yaitu: (1) permintaan laporan kepada pengelola ADD, (2) kunjungan Kepala Desa pada suatu kegiatan pengelolaan ADD, dan ada 1 bentuk kegiatan yang berada pada tangga ke-1 (manipulasi), yaitu pengawasan pengelolaan ADD yang dilakukan oleh BPD yang diasumsikan merupakan representasi dari masyarakat. Adapun yang menjadi faktor penghambat partispasi masyarakat dalam pengelolaan ADD yakni:

- Minimnya tingkat pendidikan masyarakat

Berdasarkan data dari Profil Desa tahun 2014, menunjukkan bahwa tingkat pendidikan masyarakat, mayoritas masih berpendidikan dasar, yaitu 69,37 persen berpendidikan SD, dan 9,57 persen berpendidikan SLTP. Masyarakat yag berpendidikan SLTA hanya mencapai 4,32 persen, kursus/ketrampilan 0,56 persen dan S1 3,48 persen, karena itu sangat wajar jika daya kritis masyarakat relatif sangat rendah, dan cenderung memfigurkan tokoh masyarakat sebagai panutan mereka untuk berpendapat atau bertindak. Tingkat pendidikan masyarakat yang masih rendah tersebut berimplikasi 
terhadap rendahnya daya kritis dan partisipasi masyarkat, termasuk dalam mengorganisir dirinya dalam memperjuangkan kepentingannya. Padahal pengorganisiran diri masyarakat dalam pelaksanaan pembangunan di Desa Air Mata sangat penting untuk membangun posisi tawar dalam mendesakkan berbagai persoalan yang dihadapi masyarakat desa, sehinga ide-ide dan kepentingan mereka dapat diakomodir oleh pemerintah desa.

\section{- Anggaran Penyelenggaraan}

MUSRENBANGDes yang belum memadai

Penyelenggaraan

MUSRENBANGDes partisipatif mensyaratkan adanya keterlibatan banyak pihak, memakan waktu yang lama, biaya yang tidak sedikit dan adanya peran seorang fasilitator yang mumpuni. Sementara dalam pelaksanaan MUSRENBANGDes di Desa Air Mata, menurut keterangan dari Kepala Desa Air Mata, tidak teralokasikan anggaran secara tersendiri. Karena itu, untuk dapat menyelenggarakan MUSRENBANGDes, maka Kepala Desa harus mengupayakan dengan menggunakan dana taktis. Akibat lebih lanjut, proses penyelenggaraan MUSRENBANGDes menjadi kurang berkualitas.

- Lemahnya inklusifitas terhadap partisipasi masyarakat dalam Pengelolaan ADD

Tidak adanya sinkronisasi antara regulasi mengenai pengelolaan ADD (Permendagri No 37 Tahun 2007 dan Permendagri No 113 Tahun 2014) denganPeraturan Bupati No.7 Tahun 2015 tentang Tata Cara Pengalokasian dan Penetapan Besaran Alokasi Dana Desa di Kabupaten Kupang membuat proses pelaksanaan dan pengawasan ADD tidak berlangsung secara transparan dan akuntabel dengan kadar partisipasi yang rendah. Pada prinsipnya pelaksanaan ADD dilakukan secara partisipatif, transparan dan akuntabel. Perda tersebut sangat menekankan pentingnya partisipasi masyarakat dalam pengelolaan ADD. Hanya saja dalam petunjuk operasional pelaksanaan pengelolaan ADD yang tertuang di dalam Peraturan Bupati No.7 Tahun 2015, kurang mengatur tentang pentingnya partisipasi masyarakat dalam pelaksanaan dan pengawasan pengelolaan ADD.

Perbup tersebut hanya menyebutkan, bahwa dalam pelaksanaan kegiatan pengelolaan ADD harus melibatkan unsur-unsur yang terkait dengan pengelola ADD secara riil untuk menghadirkan nilai-nilai partisipatif dan keterbukaan, dan apabila terjadi ketimpangan atau penyimpangan, bisa langsung diketahui untuk saling mengingatkan, dengan ketentuan: (1) penggunaan dana ADD sesuai dengan rencana dan kegiatan mencapai hasil yang memuaskan serta selesai tepat waktu, (2) memanfaatkan tenaga masyarakat desa setempat untuk pekerjaan yang memerlukan tenaga mereka, (3) sasaran kegiatan agar tepat untuk menghindari kecemburuan sosial.

Dengan demikian dapat diartikan bahwa petunjuk operasional pengelolaan ADD yang tertuang di dalam Peraturan Bupati, terutama pada tahap pelaksanaan dan pengawasan kurang memberikan ruang partisipasi masyarakat. Karena itu, pemerintah desa tidak bisa disalahkan jika dalam pengelolaan ADD tidak melibatkan masyarakat dalam pelaksanaan dan pengawasan $\mathrm{ADD}$, serta tidak melaporkan secara langsung mengenai hasil pelaksanaan pengelolaan ADD kepada masyarakat, tetapi cukup melaporkan kepada pemerintah supradesa dan membuat LKPJ (Laporan Keterangan Pertanggung Jawaban) hasil pengelolaan ADD kepada BPD yang diasumsikan sebagai representasi masyarakat meskipun anggota BPD tidak dipilih secara langsung oleh masyarakat.

- Kurangnya sosialisasi tentang pentingnya partisipasi masyarakat dalam pengelolaan ADD.

Banyaknya anggota masyarakat yang kurang memahami apa itu ADD, dan apa pentingnya ADD, menandakan bahwa masyarakat kurang diberikan sosialisasi tentang wujud dan urgensi ADD. Ini mengakibatkan masyarakat di Desa Air Mata tidak memiliki sense of belonging terhadap jalannya pelaksanaan ADD tersebut. Masyarakat terlihat apatis, acuh tak acuh dan kurang terlibat dalam kegiatan pengelolaan ADD mulai dari perencanaan, pelaksanaan hingga pengawasan. 


\section{Kesimpulan}

Nilai inklusifitas atau partisipasi masyarakat dalam Pengelolaan dana ADD di Desa Air Mata masih rendah atau belum mencapai apa yang diharapkan. Hal ini dapat dicermati pada tiga indikasi.

Pertama, dalam hal perencanaan dana ADD, jika menggunakan teori partisipasi dari Anstein, partisipasi masyarakat dalam kegiatan MUSRENBANGDes di DesaAir Mata tersebut baru mencapai derajat "tanda partisipasi" (tokenisme), dan berada pada tangga ke-empat yakni konsultasi (consultation). Kedua, dalam hal pelaksanaan dana ADD, partisipasi masyakarat masih sangat rendah. Jika dikaitkan dengan teori partisipasi dari Arnstein, maka partisipasi masyarakat dalam pengelolaan ADD di Desa Air Mata masih berada dalam kategori derajat partisipasi yang disebut "tanda partisipasi” (tokenism) dan berada pada tangga ke-3 yaitu pemberian informasi (informing). Ketiga, demikian pun dalam hal pengawasan, partisipasi masyarakat dalam pengawasan pengelolaan $\mathrm{ADD}$ tersebut jika dianalisis dengan menggunakan pendekatan teori partisipasi dari Anstein (dalam Wilcox, 1996) yakni ledders of participation (tangga partisipasi) maka partisipasi masyarakat dalam pengawasan pengelolaan ADD di Desa Air Mata tidak bisa dikategorikan dalam degree of citizen power. Namun masih berada dalam kategori dalam derajat partisipasi yang disebut non-partisipasi (non-participation), dan berada pada tangga ke-1 (paling bawah), yaitu "manipulasi" (manipulation). Artinya, partisipasi masyarakat dalam pengawasan pengelolaan ADD di Desa Air Mata tersebut bersifat manipulasi (manipulation).

Dalam konteks Good Governance, pengelolaan dana ADD juga belum melibatkan partisipasi masyarakat secara maksimal, yang bisa dilihat dari tiga indikasi. Pertama, dalam hal partisipasi, peserta yang diundang dan hadir dalam kegiatan MUSRENBANGDes mayoritas tokoh-tokoh formal yang tergabung dalam organisasi kemasyarakatan dan yang ada hubungan langsung dengan pemerintah desa (seperti: Ketua RT/RW, pengurus TP.PKK, Pengurus Karang Taruna, Pengurus LPMD, Anggota BPD dan lain sebagainya. Kedua, dalam hal transparansi, masyarakat kurang memahami substansi apa itu ADD, penggunaannya untuk apa dan siapa yang menjadi target sasaran dari ADD tersebut. Ketiga, dalam hal akuntabilitas, proses pengambilan keputusan memang dilakukan melalui proses dialog untuk membahas apakah draft usulan RPD (Rencana Penggunaan Dana) ADD tersebut dapat diterima dan ditetapkan ke dalam Perdes. Namun proses dialog tersebut lebih didominasi oleh elit desa dan perangkat desa, sehingga hasil keputusan yang diambil kurang mencerminkan kebutuhan masyarakat yang ditujukan untuk peningkatan pemberdayaan masyarakat. Selain itu dapat dilihat dari alokasi penggunaan dana ADD yang lebih banyak digunakan untuk biaya operasional daripada kegiatan pemberdayaan masyarakat itu sendiri, sehingga, hasil keputusan RPD-ADD kurang mencerminkan keberpihakan kepada rakyat, tetapi berpihak untuk kepentingan pemerintah desa dan elit desa. Faktor-faktor penghambat partisipasi masyarakat dalam pengelolaan ADD Di Desa Air Mata yakni: (a) tingkat pendidikan masyarakat yang masih rendah, (b) terbatasnya anggaran penyelenggaraan MUSRENBANGDes, (c) peraturan dan kebijakan Pemerintah Kabupaten Kupang dalam pengelolaan ADD kurang mengakomodir partisipasi masyarakat, (d) kurangnya sosialisasi tentang pentingnya partisipasi masyarakat dalam pengelolaan ADD.

\section{Bibliografi}

Bungin, Burhan. 2003. Analisis Penelitian Data Kualitatif: Pemahaman Filosofis dan Metodologis ke arah Penguasaan Model Aplikasi. Jakarta: Raja Grafindo.

Conyers, Diana and Hills Peter.1990. An Introduction to Development Planing in The Third World. New York: John Wiley \& Sons Chichester.

Cottam Hilary. 2010. Participatory System; Moving Beyond 20 Century Institution. Harvard International Review. 
Darmada, Wayan. 2011. Partisipasi Masyarakat Desa. Yogyakarta: Pustaka Pelajar.

Deepak Kumar Das. 2005. Community Based SosioEconomic Development Planing in Irrigaton Projects in India: Startegic Appproaches in JBIC Assisted Projects, Centre for Studies in India.

Dwipayana, dkk. 2003. Membangun Good Governance di Desa. Yogyakarta: IRE Press. Hetifah, Sj. 2009. Inovasi, Partisipasi dan Good Governance. Jakarta: Yayasan Obor.

Ife, Jim., Tesoriero, Frank. 2008. Community Development: Alternatif Pengembangan masyarakat di Era Globalisasi. Yogyakarta: Pustaka Pelajar.

Islamy, M. Irfan. 2004. Membangun Masyarakat Partisipatif. Jurnal Administrasi Publik. Volume IV Nomor 02 Maret-Agustus 2004.

Kuncoro, Mudrajad. 2019. Ekoomika Desa:

Teori, Strategi dan Realisasi Pembangunan Desa. Yogyakarta: STIM YKPN.

Lenoir, R. 1974. Lex Exlus: Un Francais Sur Dix. Paris: Seuil Publication.

Moleong, Lexy. J. 2002. Metode Penelitian Kualitatif. Bandung: Remaja Rosdakarya.

Narimawati, Umi. 2008. Metodologi Penelitian Kualitatifdan Kuantitatif: Teori dan Aplikasi. Bandung: Agung Media.
Sanusi, Anwar. 2011. Metode Penelitian Bisnis. Jakarta: Salemba Empat.

Solechan, Moch. 2014. Penyelenggaraan Pemerintahan Desa Berbasis partisipasi Masyarakat. Malang: Setara Press.

Sugiyono. 2010. Metode Penelitian Kuantitatif, Kualitatif dan R\&D. Bandung: Alfabeta.

Sutoro, Eko. 2004. Reformasi Politik dan Pemberdayaan Masyarakat. APMD Press, Yogyakarta.

Usman, Husaini. 2009. Metodologi Penelitian Sosial, Bumi Aksara, Jakarta.

\section{Daftar Peraturan}

Undang-Undang Nomor 17 Tahun 2003 tentang Keuangan Negara.

UU No.25 tahun 2004 tentang Sistem Perencanaan Pembangunan Nasional.

UU No. 6 Tahun 2014, tentang Desa.

Permendagri No 37 Tahun 2007 tentang Pedoman Pengelolaan Keuangan Desa.

Permendagri No 113 Tahun 2014 tentang Pengelolaan Keuangan Desa.

Peraturan Bupati No.7 Tahun 2015 tentang Tata Cara Pengalokasian dan Penetapan Besaran Alokasi Dana Desa di Kabupaten Kupang. 